\title{
Fenomena Kesurupan Dalam Persepsi Psikolog Dan Peruqyah
}

\author{
Syarifah \\ Universitas Islam Negeri (UIN) Antasari
}

\begin{abstract}
This study aims to compare the perceptions of psychologists and who do people ruqyah to trans possession phenomena. This research is a comparative descriptive study using a qualitative approach. The subjects of this study amounted to 6 people consisting of 3 people who work as psychologists and 3 people who work as who do people ruqyah in the Pondok Sehat Al-Wahida. Data collection techniques used are interviews, observation, and documentation. Analysis of the data used with descriptive-comparative methods.

Based on the results of the research can be concluded that there are differences and similarities of perceptions of psychologists and people who do ruqyah in viewing at the trance phenomenon in the city of Banjarmasin. The difference between the perception of psychologists and people who do ruqyah in viewing the phenomenon of trance is that psychologists view the phenomenon of possession using psychological theory, while peruqyah views the phenomenon of possession using Islamic studies so that treatment given by psychologists and people who do ruqyah has this difference in accordance with their scientific competencies. As for the similarities between the perception of psychologists and people who the ruqyah in viewing at the phenomenon of possession can be caused by psychological problems but they also believe in Islamic studies can be caused by a genie that penetrates the body,
\end{abstract}

Keywords: Perception; Psychologist; Peruqyah; Trance

\begin{abstract}
Abstrak
Penelitian ini bertujuan untuk membandingkan persepsi psikolog dan peruqyah terhadap fenomena kesurupan. Penelitian ini merupakan penelitian deskriptif komparatif dengan menggunakan pendekatan kualitatif. Subjek penelitian ini berjumlah 6 orang yang terdiri dari 3 orang yang berprofesi sebagai Psikolog di Kota Banjarmasin dan 3 orang yang berprofesi sebagai Peruqyah di Pondok Sehat Al-Wahida. Teknik pengumpulan data yang digunakan adalah wawancara, observasi, dan dokumentasi. Analisis data yang digunakan dengan metode deskriptif-komparatif.

Berdasarkan hasil penelitian ditemukan adanya perbedaan dan persamaan persepsi Psikolog dan Peruqyah dalam memandang fenomena kesurupan di kota Banjarmasin. Perbedaan persepsi Psikolog dan Peruqyah dalam memandang fenomena kesurupan adalah Psikolog memandang fenomena kesurupan menggunakan kajian teori psikologi, sedangkan Peruqyah memandang fenomena kesurupan menggunakan kajian Islam sehingga penanganan yang diberikan Psikolog dan Peruqyah dalam menangani orang yang mengalami kesurupan memiliki perbedaan hal ini sesuai dengan kompetensi keilmuwan mereka. Adapun persamaan persepsi Psikolog dan Peruqyah dalam memandang fenomena kesurupan adalah fenomena kesurupan dapat terjadi disebabkan oleh permasalahan psikologis akan tetapi mereka juga
\end{abstract}


meyakini dalam kajian Islam fenomena kesurupan dapat terjadi disebabkan oleh jin yang merasuk ke tubuh.

Kata Kunci: Persepsi; Psikolog; Peruqyah; Kesurupan

Kesurupan merupakan fenomena sosial yang sering ditemui di masyarakat baik di televisi maupun di media massa lainnya. Menurut keyakinan atau juga menurut agama, seorang yang kesurupan dikarenakan ada sosok makhluk halus yang masuk ke dalam tubuh dan mengendalikannya. Tidak sedikit orang yang kesurupan dapat berbicara ngawur dan bertingkah aneh (Merdeka, 2017).

Fenomena kesurupan menjadi tema yang menarik dalam kajian psikologi. Sebuah kajian yang mengandung kontroversi dan dipandang dari berbagai sisi yang berbeda. Dalam banyak literatur sejarah psikologi, fenomena kesurupan dianggap sebagai sebuah asumsi primitif dalam memandang gangguan jiwa. Dalam kenyataan bahwa gangguan atau penyakit mental (mental disorder) dapat bersumber dari, atau disebabkan oleh kerasukan jin yang pada dasarnya sudah lazim diterima dan diakui dalam kepercayaan agama maupun kepercayaan tradisional. Dalam Islam, penerimaan dan pengakuan dimaksud terkait erat dengan prinsip keimanan kepada yang ghaib. Dalam aliran-aliran utama psikologi dan psikoterapi modern seperti behaviorisme, psikoanalisis dan psikologi humanistik memang terlihat adanya kecenderungan yang kuat untuk mengingkari kepercayaan agama dan kepercayaan tradisional bahwa penyakit mental bersumber dari gangguan jin (kesurupan) (Susanto, 2014).

Menurut hasil studi pendahuluan yang dilakukan peneliti pada Psikolog dan Peruqyah di Kota Banjarmasin, ditemukan perbedaan persepsi dalam menanggapi fenomena kesurupan. Menurut Leavitt persepsi (perception) dalam arti luas ialah pandangan atau pengertian, yaitu bagaimana seseorang memandang atau mengartikan sesuatu (Sobur, 2003). Adapun persepsi yang dimaksud peneliti di sini adalah pandangan Psikolog dan Peruqyah terhadap objek (kesurupan). Psikolog adalah lulusan pendidikan profesi yang berkaitan dengan praktik psikologi dengan latar belakang pendidikan Sarjana psikologi lulusan program pendidikan tinggi psikologi strata 1 (S1) sistem kurikukum lama atau yang mengikuti pendidikan tinggi psikologi strata 1 (S1) dan lulus dari pendidikan profesi psikologi atau strata 2 (S2) Pendidikan Magister Psikologi (Profesi Psikolog) (Himpunan Psikologi Indonesia, 2010). Adapun Psikolog 
yang dimaksud peneliti di sini adalah Psikolog yang pernah melihat kasus kesurupan baik itu secara langsung maupun tidak langsung.

Sedangkan Peruqyah diartikan sebagai ruqyah yang berasal dari bahasa Arab dengan makna yang sangat luas. Lafadz "ruqyah" diambil dari akar kata kerja: raqa-yarqi. Secara lughawi (etimologi), ruqyah berarti al-'audzah atau at-ta'widz, yaitu: meminta perlindungan (isti'adzah) (Ghaffar \& Siraj, 2012). Dr.Yusuf Al-Qaradhawi mendefinisikan ruqyah sebagaimana dikutip oleh Musdar BustamamTambusai dengan definsi “Ar-Ruqaa” merupakan bentuk jama' (plural) dari ruqyah, yaitu (doa) perlindungan yang dibacakan kepada orang yang sakit seperti demam, kesurupan, digigit ular atau disengat kalajengking dan sebagainya, sebagaimana dibacakan pula kepada orang yang sakit disebabkan ain (Tambusai, 2010). Secara istilah sebagaimana telah disebutkan ruqyah identik dengan penyembuhan secara syar'i dengan menggunakan ayat-ayat Alquran (Musdar Bustaman, 2013). Peruqyah adalah orang yang melakukan ruqyah. Peruqyah yang dimaksud peneliti di sini adalah orang yang menyembuhkan gangguan kesurupan dengan membacakan ayat-ayat Alquran Al-Karim, nama-nama Allah, dan sifat-sifat-Nya, dan (membacakan) doa-doa yang syar'i (ma'tsurat) disertai dengan kriteria-kriteria sebagai Peruqyah. Adapun kriteria Peruqyah yang dimaksud peneliti di sini adalah Peruqyah yang pernah mengikuti pelatihan-pelatihan Peruqyah dan mendapatkan sertifikat sebagai pernyataan kelulusan dan standarisasi.

Menurut hasil wawancara awal yang dilakukan peneliti di Kota Banjarmasin ditemukan perbedaan pandangan dalam menanggapi fenomena kesurupan. Menurut Psikolog kesurupan adalah reaksi kejiwaan yang disebut dengan Dissosiatif Trance Dissorder (DTD) atau gangguan disosiasi. Gangguan disosiasi itu terjadi menurut teori Sigmund Freud dikarenakan adanya konflik konflik-konflik yang tidak terselesaikan yang masuk ke alam bawah sadar dan dipendam, ketika ada pemicu maka konflik-konflik tersebut keluar ke permukaan melalui perilaku-perilaku yang bisa kita amati itu namanya kesurupan, gangguan semacam ini termasuk gangguan mental (Dissosiatif Trance Dissorder).

Sedangkan praktisi terapis ruqyah syar'iyyah (Peruqyah) di Pondok Sehat Al-Wahida, dia menuturkan bahwa kesurupan adalah masuknya jin ke dalam tubuh manusia. Jin termasuk 
makhluk gaib sebagaimana firman Allah dalam Q.S. al-Baqarah/2: 275 yang artinya (Kementerian Agama, 2012):

"Orang-orang yang makan (mengambil) riba tidak dapat berdiri melainkan seperti berdirinya orang yang kemasukan syaitan lantaran (tekanan) penyakit gila".

Maksud ayat tersebut adalah orang yang memakan harta riba itu akan dibangkitkan di dalam kuburnya dalam keadaan seperti orang kesurupan. Faktor pemicu kesurupan karena lalai/lupa mengingat Allah, melanggar perintah Allah seperti pergi ke dukun sehingga kondisi tersebut memudahkan jin untuk masuk ke dalam tubuh, selain itu jin masuk ke tubuh manusia bisa karena ijin Allah sehingga ia mengalami kesurupan.

Dari latar belakang di atas maka peneliti tertarik untuk menggali lebih lanjut bagaimana persepsi Psikolog dan Peruqyah terhadap fenomena kesurupan dan bagaimana perbandingan persepsi Psikolog dan Peruqyah terhadap fenomena kesurupan.

Penelitian ini dilakukan untuk membandingkan persepsi Psikolog dan Peruqyah terhadap fenomena kesurupan.

\section{Metode}

Metode penelitian yang digunakan adalah deskriptif komparatif dengan pendekatan kualitatif. Metode deskriptif-komparatif dalam penelitian ini adalah dengan membandingkan persepsi antara Psikolog dengan Peruqyah terhadap fenomena kesurupan. Pendekatan kualitatif artinya data yang dikumpulkan bukan berupa angka-angka, melainkan data tersebut berdasarkan naskah wawancara, catatan lapangan, memo, dokumen pribadi, dokumen resmi lainnya (Moleong, 1991).

Penelitian ini dilakukan di Kota Banjarmasin. Subjek penelitian ini berjumlah 6 orang yang terdiri dari 3 orang yang berprofesi Psikolog yang berinisial Z, G, N bertempat di Kota Banjarmasin dan Peruqyah yang berjumlah 3 orang yang berinisial R, M, H bekerja di Pondok sehat Al-Wahida.

Teknik pengumpulan data yang digunakan adalah wawancara semi terstruktur, sebagai metode utama dan observasi sebagai metode pendukung serta dokumentasi untuk memperkuat kebenaran data yang diambil. Dokumentasi yang digunakan dalam penelitian ini 
adalah dokumen tertulis berupa sertifikat pernyataan kelulusan dan standarisasi subjek Peruqyah yang pernah mengikuti pelatihan-pelatihan ruqyah syar'iyyah.

Data yang di peroleh di analisis dengan metode deskriptif komparatif dengan menggunakan memadukan antara metode ilmiah dan perspektif agama Islam.

\section{Hasil}

Ditemukan adanya perbedaan dan persamaan persepsi Psikolog dan Peruqyah dalam menanggapi fenomena kesurupan. Perbedaan persepsi Psikolog berinisial dan Peruqyah dalam menanggapi fenomena kesurupan adalah Psikolog memandang fenomena kesurupan menggunakan kajian teori psikologi, sedangkan Peruqyah memandang fenomena kesurupan menggunakan kajian Islam sehingga dari segi penanganan yang diberikan Psikolog dan Peruqyah dalam menangani kesurupan memiliki perbedaan hal ini sesuai dengan kompetensi keilmuwan mereka.

Menurut pandangan Psikolog, kesurupan adalah kondisi hilanganya kesadaran sehingga tidak memiliki kemampuan untuk mengontrol diri yang disebabkan oleh permasalahan psikologis: adanya tekanan emosi atau pikiran yang tidak bisa dikeluarkan di alam bawah sadar, alam alam bawah sadar itu sebenarnya $88 \%$ sedangkan kesadaran itu hanya $12 \%$, sehingga akan terjadi kecenderungan emosi atau pikiran tersebut terpendam di alam bawah sadar dan mengakibatkan tekanan (stres) dalam diri. Apabila ada faktor pemicunya maka akan dilampiaskan dalam bentuk luapan emosi yang tidak terkontrol. Faktor pemicunya seperti: adanya konflik-konflik yang ada dalam dirinya belum terselesaikan, penyelesaian masalah (coping) emosi, coping stresnya buruk, mengalami stres berat, kecemasan (anxiety) yang tinggi, kepribadian tertutup, lingkungan sosial, perilaku yang ditiru (modelling) dan lain-lain.

Kesurupan tidak hanya terjadi secara individu akan tetapi dapat terjadi secara massal. Menurut pandangan Psikolog, kesurupan massal itu terjadi karena permasalahan psikologis yang dipendam sehingga mengalami tekanan dan tidak bisa di kontrol sehinggaterjadi karena luapan emosional yang kuat dan dapat mempengaruhi orang-orang yang ada di sekitar. Saat mereka melihat dan merasakan luapan emosional yang kuat dari teman mereka dalam kondisi 
"kesurupan", pada dasarnya mengarahkan mereka untuk masuk ke alam bawah sadar, tanpa tidak disadari dia meniru perilaku tersebut (modelling).

Sedangkan persamaan persepsi Psikolog dan Peruqyah terhadap fenomena kesurupan terletak bahwa Psikolog memandang fenomena kesurupan terjadi selain disebabkan oleh permasalahan psikologis akan tetapi Psikolog tetap meyakini dalam kajian Islam fenomena kesurupan dapat disebabkan oleh jin yang merasuk ke dalam tubuh dalam kondisi tekanan emosi negatif dan lemahnya iman kepada Allah. Sama halnya dengan Peruqyah, memandang dan meyakini fenomena kesurupan terjadi selain disebabkan oleh jin yang merasuk ke dalam tubuh, akan tetapi Peruqyah percaya bahwa fenomena kesurupan dapat disebabkan oleh permasalahan psikologis.

Menurut pandangan Peruqyah, kesurupan adalah kondisi hilangnya kesadaran sehingga tidak dapat mengontrol diri yang disebabkan oleh jin yang merasuk ke dalam tubuh melalui aliran darah. Adapun penyebab terjadinya kesurupan di picu oleh gangguan jin atau setan di seperti syirik kepada Allah, menyalahi sunnah Allah, memakai ilmu hitam, bermaksiat, melakukan dosa besar, memiliki benda-benda pusaka, ketidaktahuan manusia menzalimi jin sehingga jin tersebut marah, jin atau setan dikirim oleh dukun untuk masuk ke dalam tubuh manusia untuk menyakiti, mengganggu, menghalangi jodoh, membuat orang itu berwibawa (ditakuti), dan jinnya iseng suka mengganggu manusia. Selain itu, menurut pandangan Peruqyah kesurupan dapat disebabkan oleh permasalahan psikologis seperti: tekanan batin, beban pikiran, kesedihan, trauma yang menumpuk sehingga menurunkan kesadaran.

Menurut pandangan Peruqyah, penyebab terjadinya kesurupan di picu oleh permasalahan psikologi seperti: tekanan batin, beban pikiran, kesedihan, trauma yang menumpuk dan menurunkan tingkat kesadaran, pikirannya kosong, bingung, ketakutan yang luar biasa karena melihat sesuatu yang mengerikan, kecemasan yang luar biasa, panik, marah, daya emosionalnya tinggi, atau terlalu bersyahwat,galau, gelisah, depresi, sedih, putus asa, lalai berzikir kepada Allah, selain itu aspek humanitasnya yang labil atau bisa dikategorikan lemahnya iman seseorang juga dapat memicu terjadinya kesurupan. 
Kesurupan tidak hanya terjadi secara individu akan tetapi dapat terjadi secara massal. Menurut pandangan Peruqyah kesurupan massal itu terjadi karena Kesurupan massal itu terjadi disebabkan oleh: ada celah-celah pintu masuk jin/setan ke dalam tubuh untuk bisa mengganggu dan faktor psikologis yang memicu terjadinya kesurupan (tekanan batin, beban pikiran, kesedihan, trauma,pikirannya kosong, bingung, ketakutan yang luar biasa karena melihat sesuatu yang mengerikan, kecemasan yang luar biasa, panik, marah, daya emosionalnya tinggi, atau ia terlalu bersyahwat,galau, gelisah, depresi,sedih, putus asa, ia lalai berzikir kepada Allah, lemahnya iman).

Adapun perbedaan pandangan persepsi Psikolog dan Peruqyah terhadap fenomena kesurupaan terletak dari segi penanganannya yaitu Psikolog dalam menangani kesurupan dengan menggunakan pendekatan psikologi yaitu hipnoterapi yang dilakukan setelah sadar dari kesurupan dan modifikasi perilaku (behavior) yang dilakukan setelah sadar dari kesurupan. Sedangkan Peruqyah dalam menangani kesurupan dengan menggunakan pendekatan ruqyah syar'iyyah (menggunakan ayat Alquran untuk penanganannya kesurupan yang disebabkan gangguan jin atau setan) dan muhasabah (diberikan nasehat atau motivasi yang kuat untuk kesurupan yang disebabkan permasalahan psikologi) sehingga Psikolog dan Peruqyah dapat bekerjasama dalam menangani kasus kesurupan.

\section{Pembahasan}

Berdasarkan hasil penelitian dapat disimpulkan ditemukan adanya perbedaan dan persamaan persepsi Psikolog dan Peruqyah dalam menanggapi fenomena kesurupan di Kota Banjarmasin. Perbedaan persepsi Psikolog dan Peruqyah dalam menanggapi fenomena kesurupan adalah Psikolog memandang fenomena kesurupan menggunakan kajian teori psikologi, sedangkan Peruqyah memandang fenomena kesurupan menggunakan kajian Islam sehingga dari segi penanganan yang diberikan Psikolog dan Peruqyah dalam menangani kesurupan memiliki perbedaan hal ini sesuai dengan kompetensi keilmuwan mereka.

Dalam pandangan ilmiah mengenai kesurupan terutama berasal dari kalangan psikiatri dan psikologi klinis. Ada beberapa istilah dalam tulisan-tulisan berkaitan dengan kesehatan mental untuk menunjuk fenomena kesurupan dalam buku PPDGJ III yaitu dissociative trance 
disorder, possession syndrome atau possession hysterical atau possession disorderdissorder, dissociative identity disorder, dan gangguan trans dan kesurupan. Kesurupan menurut pandangan ilmiah merupakan bagian dari gangguan disosiasi, yaitu belum terintegrasinya kepribadian indivdu secara baik sehingga dalam situasi tertentu yang berkaitan dengan stres/tekanan, ada bagian kepribadian muncul secara otonom menggantikan kepribadian yang selama ini disadari (kepribadian asli) (Siswanto, 2015).

Siti Sundari menjelaskan faktor yang dominan yang dapat memicu terjadinya kesurupan adalah faktor psikologis, stres, depresi atau semacamnya. Orang yang mengalami stres mudah sekali tersugesti dengan berbagai hal dikarenakan biasanya orang yang stres itu seringkali melamun yang menandakan kosongnya pikiran sadar. Jika pikiran sadar kosong sudah pasti pikiran bawah sadarlah yang mendominasi. Menurut pandangan Freud, Disosiasi merupakan salah satu bentuk deffence mechanism ego ketika kebutuhan-kebutuhan id tidak tersalurkan karena adanya super ego. Dalam hal ini, orang yang mengalami stres berat atau kejadian traumatik, coping stres tidak dapat mengatasi stresor yang ada sehingga ego melemah. Saat ego ini melemah individu mulai melakukan pertahanan diri dalam bentuk disosiasi. yaitu suatu usaha untuk menghilangkan kesusahan atau kekecewaan dengan jalan melarikan diri dari hal-hal yang tak menyenangkan dengan cara yang tidak masuk akal (Sundari, 2005).

Hal ini selaras dengan pandangan Psikolog yang menyatakan bahwa kesurupan adalah kondisi hilanganya kesadaran sehingga tidak memiliki kemampuan untuk mengontrol diri yang disebabkan oleh permasalahan psikologis: adanya tekanan emosi atau pikiran yang tidak dapat dikeluarkan di alam bawah sadar, alam alam bawah sadar itu sebenarnya $88 \%$ sedangkan kesadaran itu hanya 12\%, sehingga akan terjadi kecenderungan emosi atau pikiran tersebut terpendam di alam bawah sadar dan mengakibatkan tekanan (stres) dalam diri. Apabila ada faktor pemicunya maka akan dilampiaskan dalam bentuk luapan emosi yang tidak terkontrol. Faktor pemicunya seperti: adanya konflik-konflik yang ada dalam dirinya belum terselesaikan, penyelesaian masalah (coping) emosi, coping stresnya buruk, mengalami stres berat, kecemasan (anxiety) yang tinggi, kepribadian tertutup, lingkungan sosial, perilaku yang ditiru (modelling) dan lain-lain. 
Kesurupan tidak hanya terjadi secara individu akan tetapi dapat terjadi secara massal. Menurut pandangan Psikolog, kesurupan massal itu terjadi karena permasalahan psikologis yang dipendam sehingga mengalami tekanan dan tidak dapat di kontrol sehinggaterjadi karena luapan emosional yang kuat dan dapat mempengaruhi orang-orang yang ada di sekitar. Saat mereka melihat dan merasakan luapan emosional yang kuat dari teman mereka dalam kondisi "kesurupan”, pada dasarnya mengarahkan mereka untuk masuk ke alam bawah sadar, tanpa tidak disadari dia meniru perilaku tersebut (modelling).

Sedangkan persamaan pandangan Psikolog dan Peruqyah terhadap fenomena kesurupan terletak bahwa Psikolog memandang fenomena kesurupan terjadi selain disebabkan oleh permasalahan psikologis akan tetapi Psikolog tetap meyakini dalam kajian Islam fenomena kesurupan dapat disebabkan oleh jin yang merasuk ke dalam tubuh dalam kondisi tekanan emosi negatif dan lemahnya iman kepada Allah. Sama halnya dengan Peruqyah memandang dan meyakini fenomena kesurupan terjadi selain disebabkan oleh jin yang merasuk ke dalam tubuh, akan tetapi Peruqyah percaya bahwa fenomena kesurupan dapat disebabkan oleh permasalahan psikologis.

Kesurupan dari pandangan Islam turut dilihat sebagai gejala kerasukan atau $(a l$-sar'u) yaitu kemasukan roh-roh jahat dari kalangan Jin dan syaitan yang memasuki badan manusia sehingga mengganggu kewarasan akal dan jiwa. Ini bertepatan dengan sabda Rasulullah SAW yang menjelaskan perihal Jin dan syaitan berupaya memasuki tubuh manusia lalu merasakan hati dan aqal manusia melalui hadith Abu Hurairah RA daripada Rasulullah bersabda yang artinya:

"Sesungguhnya syaitan berjalan pada anak manusia seperti jalannya darah pada peredarannya"(Ahmad \& Ibrahim, 2015).

Hal ini senada dengan pandangan Peruqyah bahwa kesurupan adalah kondisi hilangnya kesadaran sehingga tidak dapat mengontrol diri yang disebabkan oleh jin yang merasuk ke dalam tubuh melalui aliran darah. Adapun penyebab terjadinya kesurupan di picu oleh gangguan jin atau setan di seperti syirik kepada Allah, menyalahi sunnah Allah, memakai ilmu hitam, bermaksiat, melakukan dosa besar, memiliki benda-benda pusaka, ketidaktahuan manusia menzalimi jin sehingga jin tersebut marah, jin atau setan dikirim oleh dukun untuk 
masuk ke dalam tubuh manusia untuk menyakiti, mengganggu, menghalangi jodoh, membuat orang itu berwibawa (ditakuti),dan jinnya iseng suka mengganggu manusia. Selain itu menurut pandangan Peruqyah kesurupan dapat disebabkan oleh permasalahan psikologis seperti: tekanan batin, beban pikiran, kesedihan, trauma yang menumpuk sehingga menurunkan kesadaran.

Adapun penyebab terjadinya kesurupan yang di picu oleh permasalahan psikologi menurut pandangan Peruqyah seperti: tekanan batin, beban pikiran, kesedihan, trauma yang menumpuk dan menurunkan tingkat kesadaran,pikirannya kosong, bingung, ketakutan yang luar biasa karena melihat sesuatu yang mengerikan, kecemasan yang luar biasa, panik, marah, daya emosionalnya tinggi, atau terlalu bersyahwat, galau, gelisah, depresi, sedih, putus asa, lalai berzikir kepada Allah, selain itu aspek humanitasnya yang labil atau bisa dikategorikan lemahnya iman seseorang juga dapat memicu terjadinya kesurupan.

Kesurupan tidak hanya terjadi secara individu akan tetapi dapat terjadi secara massal. Menurut pandangan Peruqyah kesurupan massal itu terjadi karena Kesurupan massal itu terjadi disebabkan oleh: Ada celah-celah pintu masuk jin/setan ke dalam tubuh untuk bisa mengganggu dan faktor psikologis yang memicu terjadinya kesurupan (tekanan batin, beban pikiran, kesedihan, trauma,pikirannya kosong, bingung, ketakutan yang luar biasa karena melihat sesuatu yang mengerikan, kecemasan yang luar biasa, panik, marah, daya emosionalnya tinggi, atau ia terlalu bersyahwat,galau, gelisah, depresi,sedih, putus asa, ia lalai berzikir kepada Allah, lemahnya iman).

Hal ini sejalan dalam perspektif Islam menurut teori Ibnu Qayyim, kesurupan itu ada dua macam: kesurupan karena kesurupan ruh jahat dan kesurupan karena tekanan jiwa (stres). Kesurupan karena tekanan jiwa (stres) sebab dan cara penyembuhannya telah banyak diperbincangkan oleh para ahli psikologi. Adapun gila karena kesurupan ruh jahat, cara mengobatinya ialah dengan memperkuat ruh yang baik untuk membinasakan ruh yang jahat. Gunanya ialah untuk menolak pengaruh ruh jahat itu menghancurkannya, gila akibat kesurupan ini tidak bisa di analisa secara ilmiah dan tidak bisa di sembuhkan secara medis (Muhammad, t.t.). 
Menurut Abu Ayyash Raf'alhaq menjelaskan bahwa gangguan jin biasanya terjadi pada orang-orang yang mengalami kondisi-kondisi antara lain: 1) marah Sekali, 2) takut yang berlebihan, memperturutkan nafsu syahwat, 3) kelalaian/ Melamun, 4) Stres berlebihan (Raf'alhaq \& Ayyash, 2005).

Selain kondisi-kondisi di atas, dalam Alqur'an, fenomena sihir, santet, guna-guna dan sebagainya diyakini sebagai praktek yang menggunakan bantuan jin. Ini terjadi jika seseorang mempunyai perjanjian dengan jin, sebagaimana dijelaskan dalam Q.S. al-Jin/72:6 yang artinya:

"dan bahwasanya ada beberapa orang laki-laki di antara manusia meminta perlindungan kepada beberapa laki-laki di antara jin, Maka jin-jin itu menambah bagi mereka dosa dan kesalahan (Kementerian Agama, 2012).

Perbedaan pandangan persepsi Psikolog dan Peruqyah terhadap fenomena kesurupaan terletak dari segi penanganannya yaitu Psikolog dalam menangani kesurupan dengan menggunakan pendekatan psikologi yaitu hipnoterapi yang dilakukan setelah sadar dari kesurupan dan modifikasi perilaku (Behavior) yang dilakukan setelah sadar dari kesurupan. Hal ini sejalan dengan teori dalam persepektif psikologi menurut Rully teknik - teknik yang dapat digunakan dalam membantu klien yang mengalami kesurupan sebenarnya cukup rasional dan siapa saja dapat mempraktekkannya sebagaimana dikutip dalam buku The Real Art of Hypnosis. Dalam buku itu dijelaskan bagaimana perspektif hypnotherapy menyoal kesurupan dan cara penanggulangannya. Hipnoterapi adalah salah satu cabang ilmu psikologi yang mempelajari manfaat sugesti untuk mengatasi masalah pikiran, perasaan dan perilaku.

Hipnoterapi adalah salah satu cabang ilmu psikologi yang mempelajari manfaat sugesti untuk mengatasi masalah pikiran, perasaan dan perilaku (Rakhmawati, Putra, \& Perdana, 2015).

Para Peruqyah dalam menangani kesurupan dengan menggunakan pendekatan ruqyah syar'iyyah (menggunakan ayat Alquran untuk penanganannya kesurupan yang disebabkan gangguan jin atau setan) dan muhasabah (diberikan nasehat atau motivasi yang kuat untuk kesurupan yang disebabkan permasalahan psikologi). Hal ini sejalan dengan teori Ibnu 
Qayyim, kesurupan itu ada dua macam: kesurupan karena kesurupan ruh jahat dan kesurupan karena tekanan jiwa (stres). Kesurupan karena tekanan jiwa (stres) sebab dan cara penyembuhannya telah banyak diperbincangkan oleh para ahli psikologi. Adapun gila karena kesurupan ruh jahat, cara mengobatinya ialah dengan memperkuat ruh yang baik untuk membinasakan ruh yang jahat. Gunanya ialah untuk menolak pengaruh ruh jahat itu menghancurkannya, gila akibat kesurupan ini tidak bisa di analisa secara ilmiah dan tidak bisa di sembuhkan secara medis (Muhammad, t.t.).

Dr. Yusuf Al-Qaradhawi mendefinisikan ruqyah sebagaimana dikutip oleh Musdar Bustamam Tambusai dengan definsi “Ar-Ruqaa” merupakan bentuk jama' (plural) dari ruqyah, yaitu (doa) perlindungan yang dibacakan kepada orang yang sakit seperti demam, kesurupan, digigit ular atau disengat kalajengking dan sebagainya, sebagaimana dibacakan pula kepada orang yang sakit disebabkan ain (Tambusai, 2010). Sehingga tidak menutup kemungkinan Psikolog dan Peruqyah dapat bekerjasama dalam menangani kasus kesurupan.

\section{Kesimpulan}

Penelitian ini menyimpulkan bahwa pada dasarnya Psikolog dan Peruqyah memiliki pemikiran yang sama di dalam memandang fenomena kesurupan. Namun karakteristik, sumber, serta cara berfikir di dalam teori yang kedua mereka kemukakan memiliki perbedaan. Perbedaan persepsi Psikolog dan Peruqyah dalam menanggapi fenomena kesurupan adalah Psikolog memandang fenomena kesurupan menggunakan kajian teori psikologi, sedangkan Peruqyah memandang fenomena kesurupan menggunakan kajian Islam sehingga dari segi penanganan yang diberikan Psikolog dan Peruqyah dalam menangani kesurupan memiliki perbedaan hal ini sesuai dengan kompetensi keilmuwan mereka, sedangkan persamaannya terletak bahwa Psikolog memandang fenomena kesurupan terjadi selain disebabkan oleh permasalahan psikologis akan tetapi Psikolog tidak mengesampingkan keyakinannya dalam kajian Islam fenomena kesurupan dapat disebabkan oleh jin yang merasuk ke dalam tubuh, sama halnya dengan Peruqyah yang meyakini fenomena kesurupan terjadi disebabkan oleh jin yang merasuk ke dalam tubuh, akan tetapi Peruqyah percaya bahwa fenomena kesurupan 
dapat disebabkan oleh permasalahan psikologis sehingga tidak menutup kemungkinan Psikolog dan Peruqyah dapat bekerjasama dalam menangani kasus kesurupan.

\section{Saran}

Penelitian selanjutnya agar memperkaya penelitiannya dengan melihat penyusunan aitem pertanyaan wawancara secara lebih mendalam dan detil, menambah jumlah subjek penelitian agar dapat digeneralisasikan, sudut pandang yang sedikit, disarankan bagi peneliti selanjutnya perlunya penelitian lanjutan yang lebih komprehensif dan lebih daripada mendeskripsikan, baik berupa pendalaman yang lebih lagi baik berupa tambahan sudut pandang untuk memperkuat teori yang ada yang terkait dengan kesurupan.

\section{Referensi}

Ahmad, K., \& Ibrahim, M. A. H. (2015). Histeria Dari Persfektif Al-Quran dan Hadith: Satu Analisis. Journal of Al-Tamaddun, 10(2).

Ghaffar, A., \& Siraj, F. (2012). Bisikan Setan: Penyebab, Dampak dan Terapinya. Solo: Aqwam.

Himpunan Psikologi Indonesia. (2010). Kode Etik Psikologi Indonesia. Jakarta: Himpunan Psikologi Indonesia.

Kementerian Agama, R. (2012). Al-Quran dan Terjemah. Bandung: Kementerian Agama RI.

Merdeka. (2017). Pakar Kesurupan Itu Bukan Disebabkan Makhluk Halus. Diambil 22 Januari 2017, dari https://www.merdeka.com/teknologi/pakar-kesurupan-itu-bukandisebabkan-makhluk-halus-tekmistis.html

Moleong, L. J. (1991). Metodologi penelitian kualitatif. Bandung: PT Remaja Rosdakarya.

Muhammad, B. (t.t.). Alam Jin dan Setan dalam Pandangan Al-Qur'an dan Sunnah. Jakarta: Pustaka Amani.

Musdar Bustaman, T. (2013). Halal-Haram Ruqyah. Jakarta: Al-Kautsar.

Raf'alhaq, \& Ayyash, A. (2005). Buku Saku Ruqyah. Surabaya: Tsabita Grafika.

Rakhmawati, R., Putra, K. R., \& Perdana, F. R. B. P. B. (2015). Metode Keperawatan Komplementer Hipnoterapi Untuk Menurunkan Efek Stress Pasca Trauma Tingkat Sedang Pada Fase Rehabilitasi Sistem Penanggulangan Kegawatdaruratan Terpadu (SPGDT). Jurnal Keperawatan, 5(2), 178-184.

Siswanto. (2015). Psikologi Kesehatan Mental: Awas Kesurupan. Yogyakarta: CV Andi Offset.

Sobur, A. (2003). Psikologi Umum Dalam Lintasan Sejarah. Bandung: Pustaka Setia.

Sundari, S. (2005). Kesehatan Mental Dalam Kehidupan. Jakarta: Rineka Cipta.

Susanto, D. (2014). Dakwah melalui Layanan Psikoterapi Ruqyah Bagi Pasien Penderita Kesurupan. Jurnal Bimbingan Konseling Islam, 5(2), 313-333.

Tambusai, M. B. (2010). Buku Pintar Jin, Sihir dan Ruqyah Syar'iyyah. Jakarta: Al-Kautsar. 